\title{
ФОРМИРОВАНИЕ ПИХТОВЫХ ЛЕСОВ НА ТЕРРИТОРИИ СРЕДНЕЙ СИБИРИ*
}

\author{
Н.Н. Кулакова, А.А. Горошко, П.В. Михайлов, С.Л. Шевелев \\ Сибирский государственный университет науки и технологий имени академика \\ М.Ф. Решетнева
}

Российская Федерация, 660037, г. Красноярск, пр. им. Газ. «Красноярский рабочий», 31 E-mail: kulakova_nn@sibsau.ru

В работе анализируются особенности формирования лесных массивов Сибири в пределах двух лесных районов - Западно-Сибирского южно-таежного лесного и Нижнеангарского таежного. Объектами исследования явились лесные массивы с абсолютным преобладанием пихтовых древостоев, расположенных в пределах Енисейского, Чунского и Богучанского лесничеств. Целью настоящей работы явилось установление особенностей формирования таежного лесного массива с преобладанием пихтовых насаждений. Рассмотрена возрастная динамика таксационных показателей древостоев пихты сибирской зеленомошниковой группы типов леса. Дана математическая интерпретация хода развития древостоя по диаметру, высоте и запасу древесины на 1 га. В целом структура лесных массивов по средним высотам, средним диаметрам и запасам аппроксимируется функцией Гаусса. На завершающем этапе исследований было произведено распределение запаса между пихтовыми древостоями различного диаметра.

Ключевые слова: пихта сибирская, закономерности строения, средний диаметр, средняя высcoma, заnac.

\section{ВВЕДЕНИЕ}

Современное состояние лесов темнохвойной формации находится в центре внимания широкого круга специалистов. Во-первых, это связано со значительной представленностью древостоев темнохвойных пород в составе покрова бореальных, особенно горно-таежных лесов, с их экологическими функциями и хозяйственным значением. Во-вторых, с наблюдаемыми в последние десятилетия процессами нарушения их устойчивости, деградации вплоть до полного распада. На территории Сибири сосредоточено около половины лесных площадей нашей страны порядка 370 млн га. Из них, на долю темнохвойных насаждений приходится шестая часть, т.е. около 62 млн га.

Пихта сибирская (Abies sibirica L.) является одним из основных компонентов темнохвойных лесов Сибири. В середине XX века площадь, занимаемая пихтой сибирской, достигала около 18 млн. га (Некрасова, Рябинков, 1978). В настоящее время пихтовые леса занимают в 13,6 млн. га с запасом древесины свыше 2 млрд м³. Наиболее значительные их площади относятся к плоскогорьям и низкогорьям Красноярского края 7 млн га (Газизов, Юсупов, 2016). Здесь формируются лесные массивы из чистых и смешанных древостоев, чаще всего с примесью ели обыкновенной (Picea obovata L.) и сосны кедровой сибирской (Pinus sibirica Du Tour).

Крупные лесные массивы пихты сибирской расположены в сравнительно доступных местах, что создает условия для их интенсивной эксплуатации. В свою очередь интенсивное использование лесных ресурсов может привести к дестабилизации и потере биологической устойчивости пихтовых насаждений. Это может стать причиной широкого распространения патологических явлений в лесу, в том числе массового повреждения насаждений сибирским шелкопрядом (Кондаков, 2002). А сопутствующее массовое размножение стволовых вредителей или дополнительное воздействие других отрицательных природных и антропогенных факторов делают ущерб лесам особенно значительным (Лямцев, 2019).

Согласно данным I.N. Pavlova с соавторами (2020), массовое поражение пихтовых древостоев в результате комплексного биотического воздействия на территории Сибири к 
концу 2018 году достигло площади 541,4 тыс. га, а потенциальная площадь дальнейшего усыхания пихтарников в темнохвойных насаждениях может составить до 10 млн га.

Возникает необходимость анализа современного состояния формирования лесных массивов с преобладанием пихты сибирской как основы для дальнейших исследований и оценки их устойчивости как биологической системы.

Такие ученые как Н. Grossman (1959, 1961, 1963), Н.М. Глазов (1976), А.Г. Мошкалев и др. (1982), И.И. Красиков, С.Л. Шевелев (2009) в своих работах указывают на наличие математического единства в распределении древостоев в массивах леса. Так, например, о ходе лесообразовательных процессов, характере антропогенного вмешательства или влияния экзогенных факторов на эти процессы можно судить по характеру структуры лесного массива.

Целью настоящей работы являлось установление особенностей формирования лесного массива с преобладанием пихтовых насаждений в таежных лесных районах Сибири и оценка степени антропогенного воздействия на лесообразовательные процессы.

\section{ОБЪЕКТЫ И МЕТОДЫ ИССЛЕДОВАНИЯ}

Таежные лесные районы Сибири занимают значительную территорию и имеют в отдельных своих частях достаточно значимо различающиеся условия местопроизрастания (почвенные, климатические, гидрологические), что находит отражение в особенностях роста и развития лесной растительности.

Объектами исследования явились лесные массивы с абсолютным преобладанием пихтовых древостоев, расположенных в пределах Енисейского, Чунского и Богучанского лесничеств.

Выделение массива из лесного фонда лесничества осуществлялось на базе методических положений, изложенных в работе И.И. Красикова, С.Л. Шевелева (2009).

Согласно лесорастительному районированию пихтовые леса на территории данных лесничеств относятся к 2 лесным районам - Западно-Сибирскому южно-таежному лесному и Нижнеангарскому таежному (Коротков, 1963).

Исследуемые лесные массивы с преобладанием пихты сибирской включают 9499 таксационных выделов Западно-Сибирского южно-таежного лесного района и 2224 выдела Нижнеангарского таежного района.

В пихтовых древостоях объекта исследований преобладают насаждения зеленомошной группы типов леса - 68 \% в Западно-Сибирском южно-таежном лесном районе и 75 \% в Нижнеангарском таежном районе.

Методической основой проведения работ явились разработки Н. Grossman (1959, 1961, 1963), Н.М. Глазова (1976), А.Г. Мошкалева и др. (1982), И.И. Красикова, С.Л. Шевелева (2009).

\section{РЕЗУЛЬТАТЫ И ОБСУЖДЕНИЯ}

Предварительный анализ структуры лесных массивов показал, что он сформирован древостоями с преобладанием пихты сибирской, с примесью ели обыкновенной (Рicea obovata L.) и сосны кедровой сибирской (Pinus sibirica Du Tour).

Результаты первичной статистической оценки рядов средних таксационных признаков пихтовых древостоев зеленомошной группы типов леса показан в таблице 1. 
Таблица 1 - Статистическая обработка основных таксационных показателей пихтовых насаждений

\begin{tabular}{|c|c|c|c|c|c|c|}
\hline $\begin{array}{c}\text { Статистические } \\
\text { показатели }\end{array}$ & $\begin{array}{l}\text { Возраст } \\
\text { сред., лет }\end{array}$ & $\begin{array}{l}\text { Высота } \\
\text { сред., м }\end{array}$ & $\begin{array}{l}\text { Диаметр } \\
\text { сред., см }\end{array}$ & Бонитет & Полнота & $\begin{array}{c}\text { Запас, } \\
\text { м³/га }^{3}\end{array}$ \\
\hline \multicolumn{7}{|c|}{ Западно-Сибирский южно-таежный лесной район } \\
\hline Среднее значение & 99 & 17,1 & 18,6 & 3,67 & 0,65 & 169 \\
\hline Стандартная ошибка & 0,5 & 0,1 & 0,1 & 0,01 & 0,002 & 0,7 \\
\hline Стандартное отклонение & 39,9 & 4,6 & 5,8 & 0,5 & 0,1 & 58,0 \\
\hline $\begin{array}{l}\text { Коэффициент } \\
\text { варьирования, \% }\end{array}$ & 40,2 & 26,7 & 31,3 & 13,1 & 22,4 & 34,3 \\
\hline Точность опыта, \% & 0,5 & 0,3 & 0,4 & 0,2 & 0,3 & 0,4 \\
\hline \multicolumn{7}{|c|}{ Нижнеангарский таежный район } \\
\hline Среднее значение & 117 & 20,1 & 21,4 & 3,50 & 0,68 & 225 \\
\hline Стандартная ошибка & 0,8 & 0,1 & 0,1 & 0,0 & 0,004 & 1,7 \\
\hline Стандартное отклонение & 31,0 & 3,9 & 4,7 & 0,5 & 0,2 & 68,2 \\
\hline $\begin{array}{l}\text { Коэффициент } \\
\text { варьирования, \% }\end{array}$ & 26,5 & 19,2 & 21,7 & 15,4 & 22,6 & 30,3 \\
\hline Точность опыта, \% & 0,6 & 0,5 & 0,5 & 0,4 & 0,6 & 0,7 \\
\hline
\end{tabular}

Полученные данные говорят о том, что лесные массивы обоих объектов исследования представлены модальными древостоями. Средние таксационные показатели в Западно-Сибирском южно-таежном лесном несколько ниже чем в Нижнеангарском таежном районе. При относительно равных полноте и бонитете, представленные массивы несколько отличаются по возрасту, средних высоте и диаметру, а также запасу на 1 га.

Определяющим фактором в формировании как лесного массива, так и отдельных древостоев является возраст. Рассматриваемый лесной массив Западно-Сибирского южнотаежного лесного района представлен практически равномерно по группам возраста, а Нижнеангарского таежного района - в основном, спелыми и перестойными насаждениями.

На рисунке 1 показано распределение пихтовых насаждений зеленомошной группы типов леса в лесных массивах по возрасту.

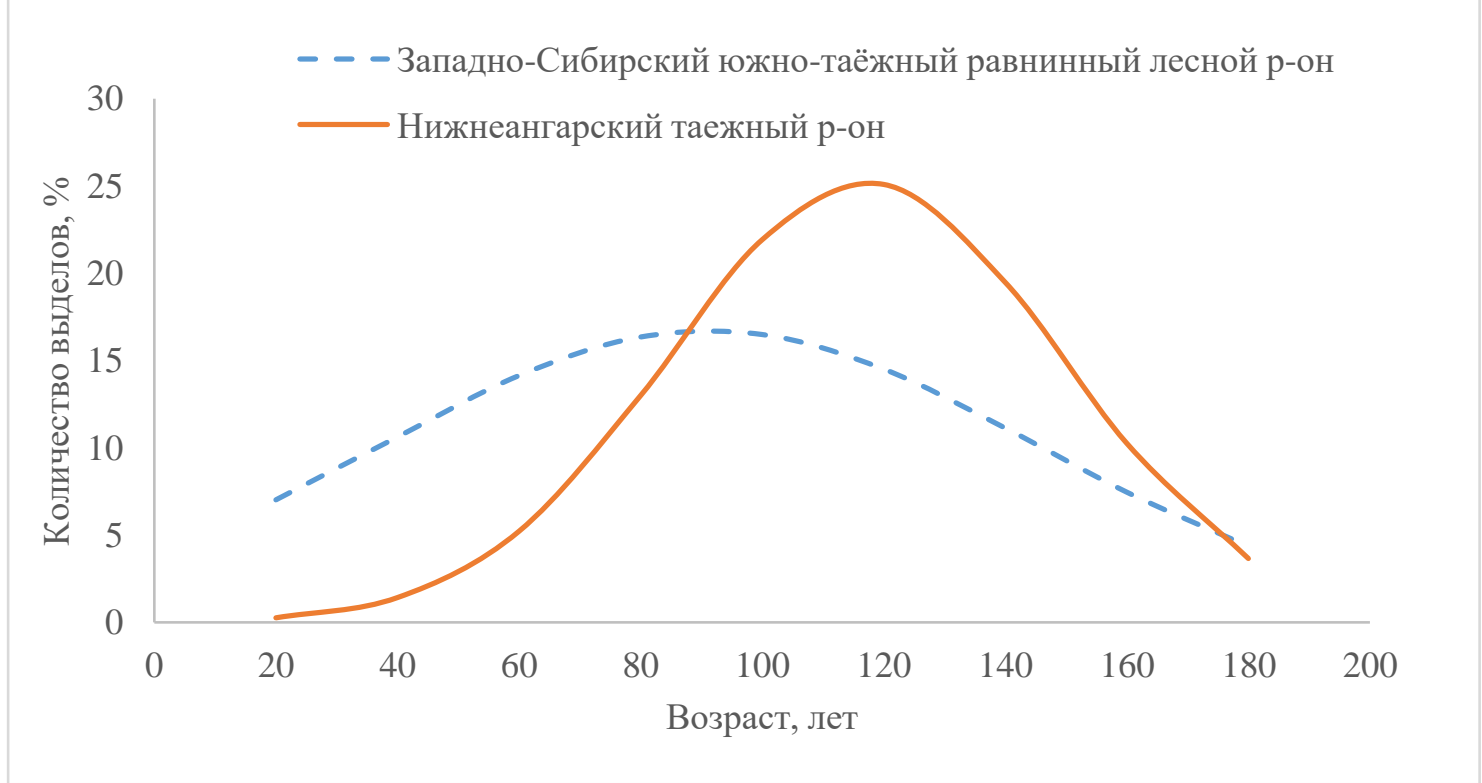

Рисунок 1 - Распределение пихтовых насаждений по возрасту 
Ряд распределения насаждений Нижнеангарского таежного района по возрасту соответствует нормальному ряду, что говорит о малой нарушенности лесных массивов этого объекта исследования. На ряд распределения насаждений Западно-Сибирского южно-таежного лесного района по возрасту значительное влияние оказала активная лесохозяйственная деятельность в районе исследования $(31,7 \%$ пихтарников зеленомошных находятся в аренде).

Анализ рядов распределения древостоев по запасу, средней высоте, среднему диаметру и относительной полноте показал, что они с высокой степенью адекватности могут быть отображены кривыми нормального вида и аппроксимированы функцией Гуасса:

$$
y=a e^{\frac{-(x-b)^{2}}{2 c^{2}}}
$$

Коэффициенты уравнений и показатели адекватности приведены в таблице 2

Таблица 2 - Коэффициенты уравнений и показатели адекватности

\begin{tabular}{|l|c|c|c|c|c|c|}
\hline \multirow{2}{*}{$\begin{array}{l}\text { Таксационный } \\
\text { показатель }\end{array}$} & \multicolumn{3}{|l|}{ Коэффициенты уравнений } & \multicolumn{2}{l}{$\begin{array}{l}\text { Коэффициент } \\
\text { детерминации } \\
\left(\mathrm{R}^{2}\right)\end{array}$} & $\begin{array}{l}\text { Стандартная } \\
\text { ошибка } \\
\text { уравнения (S) }\end{array}$ \\
\cline { 2 - 6 } & $\mathrm{a}$ & $\mathrm{b}$ & $\mathrm{c}$ & 0,663 & 7,32 \\
\hline Средний диаметр, см & 2,28 & 1,80 & 7,53 & 0,533 & 5,54 \\
\hline Средняя высота, м & 1,52 & 1,75 & 5,66 & 0,47 & 6,21 \\
\hline Средний возраст, лет & 1,67 & 9,12 & 5,41 & 0,924 & 3,62 \\
\hline Средняя полнота & 3,11 & 6,40 & 1,19 & 0,962 & 2,90 \\
\hline Запас, м ${ }^{3}$ & 3,10 & 1,70 & 6,68 & 3,87 \\
\hline \multicolumn{7}{|c|}{ Нижнеангарский таежный район } \\
\hline Средний диаметр, см & 3,80 & 2,17 & 4,01 & 0,941 & 1,63 \\
\hline Средняя высота, м & 2,84 & 2,04 & 2,72 & 0,978 & 4,11 \\
\hline Средний возраст, лет & 2,52 & 1,17 & 3,21 & 0,87 & 2,38 \\
\hline Средняя полнота & 2,80 & 6,99 & 1,37 & 0,956 & 2,04 \\
\hline Запас, м & \\
\hline
\end{tabular}

Основным таксационным показателем, определяющим его хозяйственную ценность, является запас древостоя. Структура распределения лесного массива по запасу древостоя определяет многие аспекты организации хозяйства в них. Инвентаризация лесных массивов с использованием измерительного метода таксации во многом базируется на установленных ранее закономерностях распределения запасов и их изменчивости. Анализ вариации запасов в исследуемых лесных массивах велся по группам возраста.

В таблице 3 показана изменчивость запасов пихтовых древостоев по группам возраста.

Оказалось, что запасы древостоев в представленных лесных массивах имеют различную изменчивость. Закономерно наибольшая изменчивость признака присуща молоднякам (46,7 и 78,5 \%) что отражает высокую степень их нарушенности в результате периодически возникающих низовых пожаров. Вариация запасов в средневозрастных, приспевающих, спелых и перестойных древостоях близка и лежит в пределах от 20,5 до $30,4 \%$. Высокая вариация молодняков объясняется небольшим количеством выделов, менее 10 \% обоих объектов исследования, и значительной изменчивостью запаса. 
Таблица 3 - Изменчивость запасов лесных массивов

\begin{tabular}{|l|c|c|c|c|}
\hline \multirow{2}{*}{ Показатели } & \multicolumn{4}{|c|}{ Группа возраста } \\
\cline { 2 - 5 } & молодняки & $\begin{array}{c}\text { средневозраст } \\
\text { ные }\end{array}$ & $\begin{array}{c}\text { приспеваю } \\
\text { щие }\end{array}$ & $\begin{array}{c}\text { спелые и } \\
\text { перестойные }\end{array}$ \\
\hline \multicolumn{5}{|c|}{ Западно-Сибирский южно-таежный лесной район } \\
\hline $\begin{array}{l}\text { Коэффициент вариации, } \\
\%\end{array}$ & 46,7 & 30,4 & 21,4 & 20,5 \\
\hline Точность опыта, \% & 3,1 & 0,6 & 1,0 & 0,4 \\
\hline \multicolumn{7}{|c|}{ Нижнеангарский таежный район } \\
\hline $\begin{array}{l}\text { Коэффициент вариации, } \\
\text { Точность опыта, \% }\end{array}$ & 78,5 & 29,2 & 23,0 & 24,6 \\
\hline
\end{tabular}

Одним из важнейших количественных таксационных показателей в значительной степени характеризующий хозяйственное значение древостоев и возможный выход из них сортиментов, является средний диаметр. Определенный интерес для характеристики производительности древостоев в лесном массиве имеет распределение запаса между древостоями различного диаметра (таблица 4)

Таблица 4 - Распределение запаса в древостоях различного среднего диаметра (1Западно-Сибирский южно-таежный лесной район, 2- Нижнеангарский таежный район).

\begin{tabular}{|l|c|c|c|c|c|c|c|c|c|c|c|c|c|}
\hline Д ср, см & 4 & 8 & 12 & 16 & 20 & 24 & 28 & 32 & 36 & 40 & 44 & 48 & итого \\
\hline 1Запас, \% & 0,05 & 5,21 & 19,41 & 12,04 & 23,90 & 34,70 & 4,63 & 0,03 & - & 0,01 & - & 0,02 & 100 \\
\hline 2Запас, \% & 0,16 & 0,38 & 4,34 & 15,01 & 31,55 & 40,57 & 6,78 & 1,07 & 0,14 & - & - & - & 100 \\
\hline
\end{tabular}

Оказалось, что наибольший запас в обоих лесных массивах имеют древостои со средними диаметрами 20-24 см, на их долю приходится в Западно-Сибирском южнотаежном лесном районе 58,6 \%, а в Нижнеангарскиом таежном районе 72,12 \%.

\section{ЗАКЛЮЧЕНИЕ}

В результате проведенной работы установлено, что лесные массивы, сформированные древостоями с преобладанием пихты сибирской в целом типичны для лесов Западно-Сибирского южно-таежного лесного и Нижнеангарского таежного районов. Лесной массив Нижнеангарского таежного района характеризуется значительной долей спелых и перестойных древостоев, что говорит о его малой нарушенности. Это подтверждается и характером рядов распределения основных таксационных признаков насаждений, которые с высокой степенью адекватности, аппроксимируются функцией, соответствующей нормальному распределению. а на массив Западно-Сибирского южнотаежного лесного района значительное влияние оказывает активная лесоэксплуатация и комплексное биотическое воздействие.

Пихтовые древостои представленных лесных массивов крупномерны и достигают среднего диаметра 48 см. Однако, основная доля запасов исследованных двух лесных массивов приходится на древостои, имеющие средние диаметры 20-24 см.

\section{БИБЛИОГРАФИЧЕСКИЙ СПИСОК}

1. Газизов А. М., Юсупов С. А.Современное состояние использования пихтовых лесов/А. М. Газизов, С. А. Юсупов // Символ науки. 2016. №11-2. С 18-19. 
2. Глазов Н.М. Статистический метод в таксации и лесоустройстве [Текст] / Н.М. Глазов. - М.: Лесная промыш- ленность, 1976. - 144 с.

3. Кондаков Ю.П. Массовые размножения сибирского шелкопряда в лесах Красноярского края // Энтомологические исследования в Сибири. 2002. Вып. 2. С. 25-74.

4. Коротков И.А. Лесорастительное районирование России и республик бывшего СССР [Текст]/ И.А. Коротков // В кн. Углерод в экосистеме лесов и болот России под.ред. В.А. Алексеева, Р.А. Бердси.- Красноярск, 1994.-170 с.

5. Красиков И.И. Структура лесных массивов в Республике Тыва / И.И. Красиков, С.Л. Шевелев. - Красноярск: СибГТУ, 2013. - 119 с.

6. Лямцев Н.И. Оценка и прогноз угрозы массового размножения сибирского шелкопряда в лесах Красноярского края/Н.И. Лямцев // Известия Санкт-Петербургской лесотехнической академии. 2019 (228) - С. 294-311

7. Мошкалев, А. Г. Таксация товарной структуры / А. Г. Мошкалев, А. А. Книзе, Н. И. Ксенофонтов, Н. С. Уланов. - М. : Лесная промышленность. - 1982. - 160 с.

8. Некрасова Т.П. Плодоношение пихты сибирской / Т. П. Некрасова, А. П. Рябинков ; отв. ред. И. Ю. Коропачинский ; Акад. наук СССР, Сиб. отд-ние, Ин-т леса и древесины им. В. Н. Сукачева. - Новосибирск : Наука, Сибирское отделение, 1978. - 148 с.

9. Шевелев С.Л. Структура лесных массивов в республике Тыва / С.Л Шевелев, И.И. Красиков // Журнал «Хвойные бореальной зоны». - 2009. т. XXVI № 2-2.c.266-273.

10. Grossman, H. Die Hohe der Variabilitats koeffizienten der Massenhaltigkeit in Abhangigkeit von verschidenen Faktoren und ihre Bedeutung fur Forstwesen / H. Grossman, 10, h-3. - 1961. - S. 328-330.

11. Grossman, H. Ergebnisse der in Jare 1957 durchgefuhrten Holzvorrats und Zuwachsinventur im Plenterwald Keula / H. Grossman // «Arch. Fur Ferstwesen», 1959. - S. 666-680.

12. Grossman, H. Versuche zur Rationalisierung der Met ho- dik von Holzvarrotsinventuren auf mathematisch - statistischer Grundlage / H. Grossman, G. Wolff. $/ / \ll$ Arch. Fur Ferstwesen» 12, 1963. - S. 77-101

13. Pavlov, I.N. Mass Reproduction of Polygraphus proximus Blandford in Fir Forests of Siberia Infected with Root and Stem Pathogens: Monitoring, Patterns, and Biological Control // I.N. Pavlov, Y.A. Litovka, D.V. Golubev, et al. //Contemporary Problems of Ecology. 2020. T. 13, P. $71-84$

* Работа выполнена в рамках государственного задания Минобрнауки России на выполнение коллективом научной лаборатории «Защита леса» проекта «Фундаментальные основы защиты лесов от энтомо- и фитовредителей в Сибири» (№ FEFE-2020-0014). 